\title{
Fertirrigation with sugarcane vinasse: Foreseeing potential impacts on soil and water resources through vinasse characterization
}

\author{
Lucas T. Fuess, Isabella J. Rodrigues \& Marcelo L. Garcia
}

To cite this article: Lucas T. Fuess, Isabella J. Rodrigues \& Marcelo L. Garcia (2017) Fertirrigation with sugarcane vinasse: Foreseeing potential impacts on soil and water resources through vinasse characterization, Journal of Environmental Science and Health, Part A, 52:11, 1063-1072, DOI: 10.1080/10934529.2017.1338892

To link to this article: https://doi.org/10.1080/10934529.2017.1338892

$$
\text { 里 Published online: } 24 \text { Jul } 2017 .
$$

\section{Submit your article to this journal $\llbracket$}

Llll Article views: 163

View Crossmark data ¿

Citing articles: 3 View citing articles $\longleftarrow$ 


\title{
Fertirrigation with sugarcane vinasse: Foreseeing potential impacts on soil and water resources through vinasse characterization
}

\author{
Lucas T. Fuess $^{a}$, Isabella J. Rodrigues ${ }^{b}$, and Marcelo L. Garcia ${ }^{b}$ \\ ${ }^{a}$ Biological Processes Laboratory (LPB), São Carlos School of Engineering (EESC), University of São Paulo (USP), São Carlos, São Paulo, Brazil; 'bão Paulo \\ State University (UNESP), Institute of Geosciences and Exact Sciences (IGCE), Rio Claro, São Paulo, Brazil
}

\begin{abstract}
This paper reports the characterization of the polluting potential of sugarcane vinasse, the main wastewater from ethanol production. Compositional data from vinasse samples collected from sugarcane biorefineries were used to predict negative effects on the soil, water resources and crops potentially associated with fertirrigation, the primary final destination of vinasse in Brazil. High risks of soil salinization were associated with the land disposal of vinasse, as evidenced by the high levels of total dissolved solids (TDS; $\left.>4,000 \mathrm{mg} \mathrm{L}^{-1}\right)$ and electrical conductivity $\left(>6.7 \mathrm{dS} \mathrm{m}^{-1}\right)$. The high TDS levels coupled with the high biodegradable organic content of vinasse $\left(>14 \mathrm{~g} \mathrm{~L}^{-1}\right)$ also favor organic overloading events, leading to local anaerobiosis conditions. Conversely, soil sodification should not be observed in areas fertirrigated with sugarcane vinasse, given the low $\mathrm{Na}$ concentrations $\left(<66 \mathrm{mg} \mathrm{L}^{-1}\right)$ relative to $\mathrm{Mg}\left(>145.1 \mathrm{mg} \mathrm{L}^{-1}\right)$ and $\mathrm{Ca}\left(>458.4 \mathrm{mg} \mathrm{L}^{-1}\right)$ levels. Priority pollutants $(\mathrm{Cu}, \mathrm{Cr}, \mathrm{Ni}, \mathrm{Pb}$ and $\mathrm{Zn}$ ) and phytotoxic elements (Al and $\mathrm{Fe}$ ) were also found in the analyzed samples; however, relevant environmental impacts should not be associated with these particular constituents. Overall, the relatively simple methodology used herein could efficiently replace massive field data collection to provide a basic understanding of the fate of vinasse in the environment in order to highlight the priority points to be considered in the management of this effluent. In summary, the prompt implementation of treatment plants in distilleries, in addition to a continuous and broad compositional characterization of vinasse, is essential to guarantee its adequate reuse.
\end{abstract}

\section{ARTICLE HISTORY}

Received 17 February 2017

Accepted 26 April 2017

\section{KEYWORDS}

Fertirrigation; negative effects' prediction; polluting potential; priority pollutants; sugarcane biorefinery; vinasse management

\section{Introduction}

Biofuel industries have accumulated important advantages in recent decades, based initially on an effort to overcome difficulties associated with the trade of fossil fuels, especially after the oil crises in the 1970s. ${ }^{[1]}$ Later, the worldwide concerns over global warming also stimulated massive research on alternative energy sources, focusing on the development and improvement of clean technologies to gradually replace the use of fossil energy, consequently reducing environmental impacts. In this context, the bioethanol industry should be highlighted, based on its worldwide technological consolidation and the suitability to use a wide variety of crops as raw materials, such as sugarcane, corn, sweet sorghum and sugar beet. ${ }^{[2,3]}$ Currently, USA and Brazil are characterized as the largest ethanol producers at a global scale, based on the use of corn and sugarcane, respectively, as the main feedstocks and accounting for over $80 \%$ of the world ethanol production. Ethanol production in Brazil reached approximately 28.7 billion liters in the 2014/2015 harvest, ${ }^{[4]}$ whereas 56.0 billion liters $(14,806 \mathrm{MMgal})$ of ethanol was obtained from the US corn-to-ethanol industry in 2015. ${ }^{[5]}$

Despite the lower absolute ethanol production, the Brazilian sugarcane-to-ethanol industry yields important environmental and economic advantages compared to the use of other feedstocks, such as (1) higher agricultural productivities, i.e., 7 $\mathrm{m}^{3} \mathrm{ha}^{-1}$ versus $3-4 \mathrm{~m}^{3} \mathrm{ha}^{-1}$ compared to corn and cassava; ${ }^{[6]}$ (2) the coupling between sugar and ethanol production chains, which provides flexibility to the process, depending on the market price of both products; ${ }^{[7,8]}$ and (3) the achievement of much higher energy output/input ratios (8-10) compared to other feedstocks ( $<2$ for sugar beet, wheat straw and corn) due to the use of lignocellulosic residues as raw materials in cogeneration systems for electricity and steam production. ${ }^{[9]}$ Moreover, some intrinsic environmental benefits of ethanol production and use, such as its renewable characteristics and the potential to reduce the emissions of greenhouse gases, reinforce its worldwide importance as a bioenergy source. However, focusing on the Brazilian case, the environmental adequacy of this process still depends directly on the proper management of vinasse, the main wastewater from ethanol production.

Vinasse constitutes a dark-brown high-strength wastewater characterized by high concentrations of organic matter and acidic compounds. ${ }^{[3,10]}$ Vinasse streams which result from sugarcane processing also present high levels of sulfate due to the use of sulfuric acid in specific steps of both sugar and ethanol production. ${ }^{[8]}$ The reference literature indicates different technological approaches to the management of vinasse, including

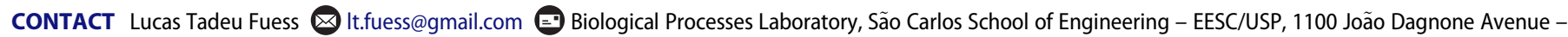
Santa Angelina, 13563-120 São Carlos, São Paulo, Brazil.

Color versions of one or more of the figures in the article can be found online at www.tandfonline.com/lesa.

(c) 2017 Taylor \& Francis Group, LLC 
concentration for volume reduction and/or animal feed production, ${ }^{[11]}$ incineration for the simultaneous production of energy and nutrient-rich ashes, ${ }^{[12]}$ biological conversion via anaerobic processes for bioenergy recovery through biogas production $^{[8,13]}$ and a return to the agricultural fields for crop irrigation and fertilization processes. ${ }^{[3]}$ Appreciable levels of macro- and micronutrients, mainly potassium, are observed in sugarcane vinasse, which favors the direct use of this wastewater in agricultural fields through fertirrigation.

Fertirrigation is virtually characterized as the only approach for the management of vinasse in Brazil; there are two main drawbacks of this practice, considering both environmental and energetic aspects. First, although some studies indicate beneficial results from the land disposal of vinasse, ${ }^{[14-16]}$ considering short-term applications (i.e., from a few months to two to three years), its continuous disposal in sugarcane crops tends to generate a wide range of negative effects on soils, water resources and crops due to the polluting characteristics of vinasse. ${ }^{[3]}$ Second, the high biodegradable organic content usually found in vinasse characterizes this wastewater as a highly energetic byproduct from the ethanol production chain; thus, fertigation also promotes a bioenergy loss.

This study focuses on the environmental drawbacks of disposing sugarcane vinasse into agricultural fields in an effort to understand the effects of applying high levels of organic matter and salts to cultivation systems. The reference literature, regarding mainly technical and legal aspects, is still incipient in terms of presenting critical content describing the effects of sugarcane vinasse on the environment, although the need for reducing the polluting load of vinasse is often discussed by the scientific community. ${ }^{[3,17,18]}$ Therefore, this paper aims to characterize the actual polluting potential of sugarcane vinasse using compositional data to predict the negative effects on the soil, water resources and crops. Potential risks associated with the contamination due to toxic metals, which are seldom discussed when considering the land disposal of sugarcane vinasse, are also analyzed. This document aims to provide useful information to decision makers in the sucro-energetic sector to properly understand the fate of vinasse in the environment through the application of a simple methodology, i.e., using relatively simple compositional data and reducing the need for massive field data collection.

\section{Materials and methods}

\section{Sugarcane vinasse sampling}

Vinasse samples were collected from four sugarcane-based biorefineries, namely DsSJ, DsSL, DsFr and DsSM, located in the South-Central Brazil. These distilleries are characterized by sugar and ethanol production processes typically found in the Brazilian sucro-alcohol industry (Fig. 1), providing representative data for vinasse characterization, as the South-Central region accounts for over $85 \%$ of the sugarcane harvesting area in Brazil as well as approximately $95 \%$ of the Brazilian ethanol production. ${ }^{[4]}$ The sampling was performed specifically at the end of the sugarcane harvest in an attempt to identify the accumulation of major compounds in vinasse, such as sulfates (due to the continuous use of sulfuric acid in the prevention of microbial contamination in fermentation vessels) and organic matter (considering possible performance losses in the fermentation process due to reductions in yeast viability).

\section{Physical-chemical characterization and analytical methods}

Sugarcane vinasse samples were initially analyzed according to the following parameters: biochemical (BOD) and chemical (COD) oxygen demands, total Kjeldahl nitrogen (TKN), total dissolved solids (TDS), electrical conductivity (EC), sulfate $\left(\mathrm{SO}_{4}{ }^{2-}\right)$, potassium $(\mathrm{K})$, phosphorus $(\mathrm{P})$, sodium $(\mathrm{Na})$, calcium $(\mathrm{Ca})$, magnesium $(\mathrm{Mg})$ and $\mathrm{pH}$. Specific metals were also identified in the samples, including aluminum (Al), cadmium $(\mathrm{Cd})$, lead $(\mathrm{Pb})$, copper $(\mathrm{Cu})$, chromium $(\mathrm{Cr})$, iron $(\mathrm{Fe})$, manganese $(\mathrm{Mn})$, molybdenum (Mo), nickel $(\mathrm{Ni})$ and zinc $(\mathrm{Zn})$. The measurements of the $\mathrm{BOD}, \mathrm{COD}$ and $\mathrm{SO}_{4}{ }^{2-}$ were performed according to the procedures described in the Standard Methods for the Examination of Water and Wastewater ${ }^{[19]}$ (methods 5210 B - 5-Day BOD Test, 5220 D - Closed Reflux, Colorimetric Method, and 4500-SO ${ }_{4}^{2-} \mathrm{E}-$ Turbidimetric Method). TKN measurements were based on semi-automated colorimetry using method 351.2. ${ }^{[20]}$ The determination of the selected metals was performed via inductively coupled plasma-optical emission spectrometry. The samples were first subjected to microwave-assisted acid digestion (method 3015A; $\mathrm{EPA}^{[21]}$ ) and then analyzed using a spectrometer (model iCAP 6300 Duo, Thermo Fisher Scientific Inc., Waltham, MA, USA) using method 200.7. ${ }^{\text {[22] }}$

\section{Polluting potential assessment}

Data regarding the physical-chemical characterization were used to discuss/predict potential implications of the land disposal of sugarcane vinasse, considering the impacts on the soil, water resources and crops. The experimental data were compared with reference values obtained from the environmental legislation and normative instructions regulating both the use of vinasse (and wastewaters in general) as a fertilizer and the water discharge of effluents. The primary documents used as references included Technical Standard P 4.231 "Vinasse - criteria and procedures for the application into agricultural soil," ${ }^{[23]}$ CONAMA Resolution 430/11, ${ }^{[24]}$ which deals with the criteria for the discharge of wastewaters into water bodies, "Guidelines for the safe use of wastewater, excreta and greywater - wastewater use in agriculture"[25] and "2012 Guidelines for water reuse," ${ }^{[26]}$ which also addresses the rational reuse of wastewater streams to obtain benefits for both human health and the environment.

\section{Results and discussion}

\section{Potential negative effects of fertirrigation}

The compositional characterization of the sugarcane vinasse samples obtained from the four distilleries is presented in Table 1, with an emphasis on the concentration of organic matter and nutrients. Comparative compositional data from other conventional feedstocks used in ethanol production, i.e., 




Figure 1. Simplified flowchart of Brazilian annexed sugarcane-based biorefineries for the production of sugar, ethanol and electricity.

sugarcane and beet molasses and corn, are also presented in Table 1. The high levels of potassium observed in sugarcane vinasse (up to $4,010 \mathrm{mg} \mathrm{L}^{-1}$ in the analyzed samples and ranging from 7,000 to $13,000 \mathrm{mg} \mathrm{L}^{-1}$ for vinasses from sugarcane molasses - Table 1) characterize the primary reason for the land disposal of this effluent, as the natural availability of potassium is relatively low. Although potassium accounts for up to $3 \%$ of the lithosphere composition, it shows low suitability for natural leaching, i.e., low mobility because it is strongly bound to other elements within the crystalline structure of the minerals. ${ }^{[25,27]}$ The content of potassium in soils commonly used in the cultivation of sugarcane accounts for less than $5 \%$ of the soil's cation exchange capacity (CEC). ${ }^{[15,16,28]}$ Consequently, the application of sugarcane vinasse is an attractive alternative to mineral fertilization, enabling reductions of approximately $50 \%$ in the application of synthetic fertilizers in terms of supplying potassium. ${ }^{[29]}$ However, the transportation of vinasse to the agricultural field (either using trucks or pipelines) depends strictly on the radius of economic distribution, ${ }^{[30]}$ which limits the distance from which the transportation of the effluent is economically unfeasible (Fig. 2) and indicates that mineral fertilization is more attractive. Thus, due to the definition of the economic radius, the generated vinasse will not be applied throughout the entire area of sugarcane cultivation (Fig. 2), suggesting the concentration of a wide variety of organic and inorganic compounds (Table 1) within a specific region of the agricultural soils.

The potential environmental impacts of the continuous long-term land disposal of sugarcane vinasse as well as their direct implications are summarized in Table 2 based on the use of reference values to classify these impacts as high or low. Soil salinization constitutes the primary negative effect of the reuse of wastewaters for fertirrigation purposes, as the continuous application of these residual streams will inevitably lead to the accumulation of salts within the soils. ${ }^{[25]}$ The values obtained for both EC $\left(>6.7 \mathrm{dS} \mathrm{m}^{-1}\right)$ and TDS $\left(>4,000 \mathrm{mg} \mathrm{L}^{-1}\right)$ for the analyzed samples (Table 1 ) are much higher than the reference values for the safe land application of wastewaters, i.e., $3.0 \mathrm{dS}$ $\mathrm{m}^{-1}$ (EC) and $500 \mathrm{mg} \mathrm{L}^{-1}$ (TDS), ${ }^{[25]}$ associating a high risk of soil salinization with the land disposal of sugarcane vinasse 


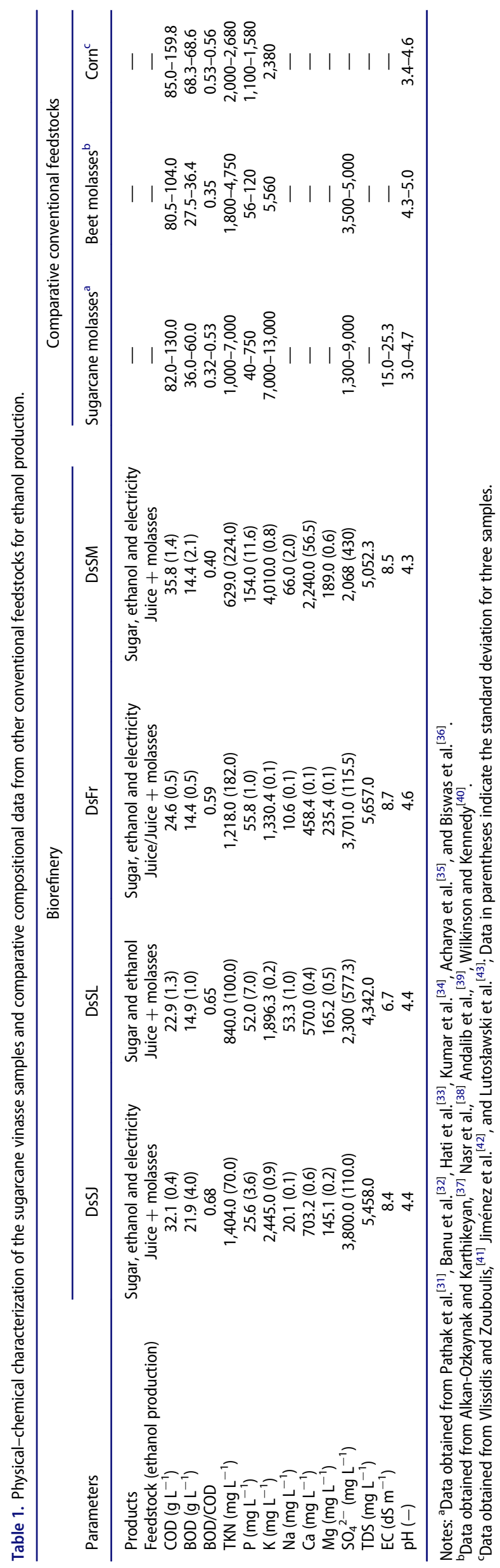




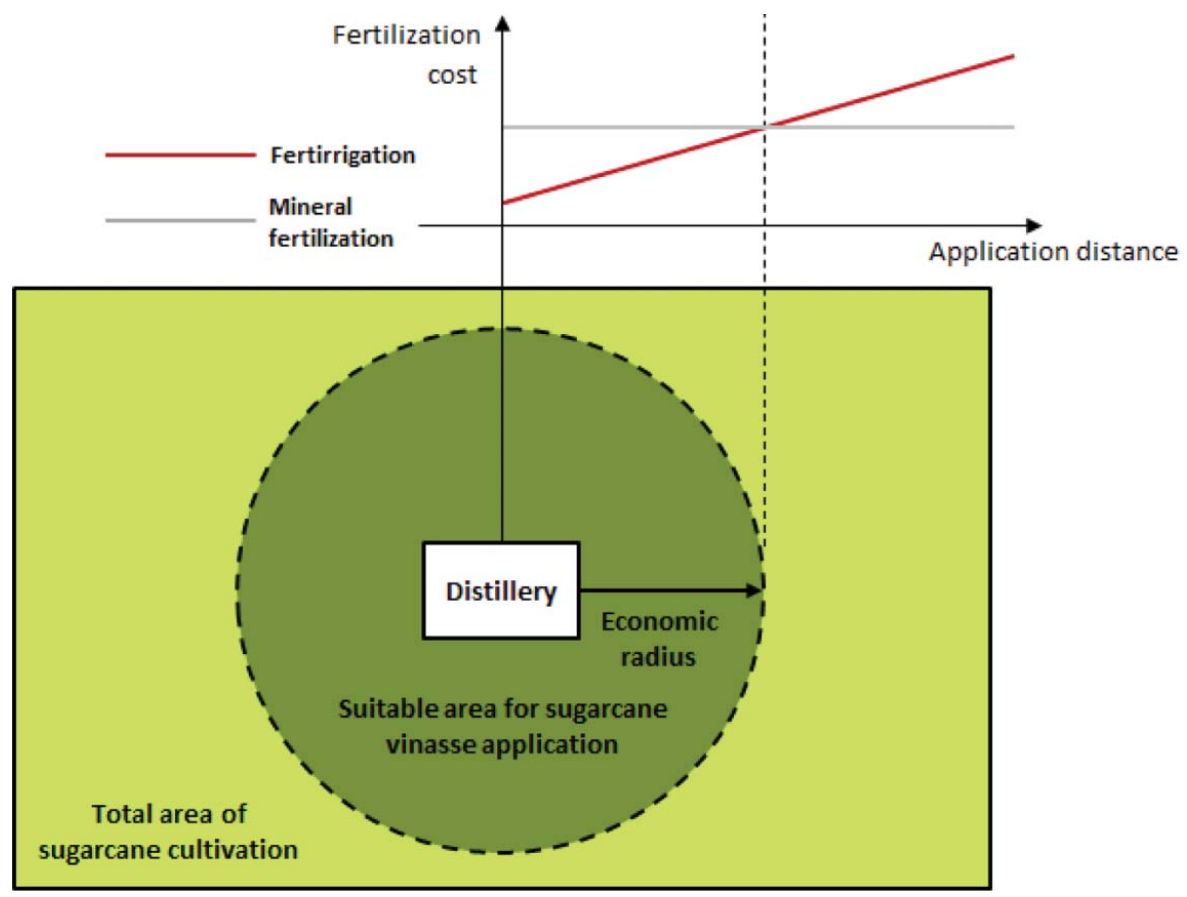

Figure 2. Economic radius for the transportation of sugarcane vinasse. Note: The definition of the economic feasibility of the application strictly depends on the costs of both transportation and mineral fertilization.

(Table 2). Special attention should focus on the role of potassium as a potential dispersive agent, which appears to be dependent on the mineral composition of the soil. ${ }^{[27]}$ Although the reference literature may still be considered inconclusive in terms of the application of excessive potassium concentrations to soils, previous studies indicated the anticipation of the runoff for up to $5 \mathrm{~min}$ in soils subjected to these conditions, ${ }^{[44]}$ characterizing losses in the hydraulic conductivity of the system. Auerswald et al..$^{[4]}$ also reported high concentrations of sediments $\left(15 \mathrm{~g} \mathrm{~L}^{-1}\right)$ in water, which evidenced the disruption of the soil structure due to the high inputs of potassium. These effects may be amplified when considering the limitations that the economic radius imposes on the available area for vinasse application (Fig. 2), as studies in these areas have reported potassium levels over $2,000 \mathrm{~kg} \mathrm{ha}^{-1},{ }^{[31]}$ which considerably exceed the potassium requirements in most crops, i.e., $185 \mathrm{~kg}$ $\mathrm{ha}^{-1}{ }^{[25]}$ However, note that salt concentrations in vinasses resulting from the direct processing of molasses (sugarcane and beet, Table 1) tend to be much higher than those of processes that use the juice, as observed for the analyzed samples. Molasses is a residual stream from sugar production obtained after the steps of evaporation and crystallization; high levels of organic and inorganic compounds result from the successive steps of water removal during the concentration of the juice (Fig. 1). In contrast to the Brazilian case, the direct use of sugarcane molasses in ethanol production is performed in the Indian sucro-alcohol industry, ${ }^{[45]}$ as it is the juice utilized solely for sugar production.

Excessive inputs of sodium also generate important negative effects on the soil structure due to the process of sodification, which constitutes a specific type of soil salinization. Soil sodification is triggered when sodium concentrations are much higher than the levels of calcium and magnesium, leading to the disruption of the soil structure and severely decreasing the infiltration rates of water (Table 2). ${ }^{[25,47,48]}$ Two specific parameters are considered to identify the risks of sodification when applying wastewaters to soils, namely the sodium:calcium (Na: Ca) ratio and the sodium adsorption ratio (SAR - Eq. (1) in which the terms $\mathrm{Na}, \mathrm{Ca}$ and $\mathrm{Mg}$ are the concentrations of sodium, calcium and magnesium in $\mathrm{mEq} \mathrm{L}^{-1}$, respectively). The values obtained for both the Na:Ca ratio $(<0.09: 1)$ and the SAR $(<0.51)$ are considerably lower than the reference values, i.e., 3:1 (Na:Ca) and 15 (SAR) (Table 2), indicating that sodification should not be observed when applying sugarcane vinasse to the soil. This pattern is considerably different from the findings reported by Tejada and Gonzalez ${ }^{[47]}$ and Tejada et al., ${ }^{[48]}$ which associated a value of over 700 with the SAR in vinasse samples resulting from the processing of sugar beet. These authors associated a series of negative effects with the land disposal of sugar beet vinasse into arid soil, such as reductions in the structural stability (25.2\%), an increase in the bulk density (22.9\%) and an expressive reduction of the microbial activity of the soil $(45.0 \%)$. Increasing values of the bulk density evidence the accumulation of fine particles within the soil pores, whereas losses in the microbial activity most likely result from the establishment of local anaerobic regions.

$$
\mathrm{SAR}=\frac{\mathrm{Na}}{[(\mathrm{Ca}+\mathrm{Mg}) / 2]^{1 / 2}}
$$

The establishment of anaerobiosis in soils amended with vinasse favors the release of malodors due to the reduction of the high levels of sulfate (up to $3,800 \mathrm{mg} \mathrm{L}^{-1}$, Table 1) into sulfide by specific microbial groups. In addition to an unpleasant odor, sulfide may hamper the nutrient uptake by plants (e.g., $\mathrm{N}, \mathrm{P}$ and $\mathrm{Fe}$ ), directly affecting the metabolism of cells and increasing root losses, ${ }^{[49]}$ although there is a limited knowledge 
Table 2. Breakdown of the potential impacts associated with the soil fertirrigation with sugarcane vinasse.

\begin{tabular}{|c|c|c|c|c|}
\hline Adverse effect & Implications & Reference parameters ${ }^{\mathrm{a}}$ & $\begin{array}{c}\text { Characteristics of the } \\
\text { vinasse }\end{array}$ & Risk \\
\hline Soil salinization & $\begin{array}{l}\text { Reduction in the osmotic potential of the soil } \\
\text { Toxicity of specific ions }\left(\mathrm{SO}_{4}{ }^{2-}, \mathrm{Na}^{+}, \mathrm{K}^{+}\right) \\
\text {Reduction in the uptake of water and nutrients by } \\
\quad \text { plants } \\
\text { Disruption of the soil structure } \\
\text { Leaching of salts to groundwater }\end{array}$ & $\begin{array}{l}\mathrm{EC}>3.0 \mathrm{dS} \mathrm{m} \mathrm{mg}^{-1} \\
\mathrm{TDS}>500 \mathrm{mg} \mathrm{L}^{-1}\end{array}$ & $\begin{array}{l}\mathrm{EC}>6.7 \mathrm{dS} \mathrm{m} \mathrm{m}^{-1} \\
\mathrm{TDS}>4,000 \mathrm{mg} \mathrm{L}^{-1}\end{array}$ & High \\
\hline Soil sodification & $\begin{array}{l}\text { Disruption of the soil structure } \\
\text { Severe reduction in the water infiltration rate } \\
\text { Burning and necrosis of the leaf tissue in plants }\end{array}$ & $\begin{array}{l}\mathrm{Na}: \mathrm{Ca}>3: 1 \\
\mathrm{SAR}^{\mathrm{b}}>15\end{array}$ & $\begin{array}{l}\mathrm{Na}: \mathrm{Ca}<0.09: 1 \\
\mathrm{SAR}<0.51\end{array}$ & Low-to-null \\
\hline $\begin{array}{l}\text { Organic overloading (soil and } \\
\text { water bodies) }\end{array}$ & $\begin{array}{l}\text { Depletion of oxygen levels } \\
\text { Establishment of local anaerobic conditions } \\
\text { Reduction in the microbial activityc } \\
\text { Increase in the structural instability of the soil }\end{array}$ & $\begin{array}{l}\mathrm{BOD}>400 \mathrm{mg} \mathrm{L}^{-1} \\
\mathrm{TDS}>500 \mathrm{mg} \mathrm{L}^{-} 1\end{array}$ & $\begin{array}{l}\text { BOD }>14,400 \mathrm{mg} \mathrm{L}^{-1} \\
\mathrm{TDS}>4,000 \mathrm{~m} \mathrm{~L}^{-1}\end{array}$ & High \\
\hline $\begin{array}{l}\text { Soil overfertilization (excess } \\
\text { of } N \text { and } P \text { ) }\end{array}$ & $\begin{array}{l}\text { Increase in the succulency of the plants } \\
\text { Alterations in both nitrifying and denitrifying } \\
\quad \text { activity of the soil } \\
\text { Depletion of oxygen levels by nitrifying bacteria } \\
\text { Potential release of nitrogen oxides }\left(\mathrm{N}_{2} \mathrm{O}\right) \\
\text { Toxicity of ammonia }\left(\mathrm{NH}_{3}\right) \text { (aquatic organisms) } \\
\text { Leaching of nitrates }\left(\mathrm{NO}_{3}{ }^{-}\right)^{\mathrm{e}} \\
\text { Eutrophication of water bodies (excess of } \mathrm{P})\end{array}$ & $\begin{array}{l}\mathrm{N} \text { : effects may be observed when TKN > } \\
\quad 30 \mathrm{mg} \mathrm{L}^{-1} \\
\text { P: the literature does not indicate } \\
\text { reference values }\end{array}$ & TKN > $629 \mathrm{mg} \mathrm{L}^{-1}$ & $\operatorname{High}^{f}$ \\
\hline $\begin{array}{l}\text { Permanent acidification (soil } \\
\text { and water) }\end{array}$ & $\begin{array}{l}\text { Alteration in the buffer capacity of the soil } \\
\text { Solubilization of phytotoxic metals (Al and Fe) } \\
\text { Reduction in the productivity of the crop } \\
\text { Reduction in the microbial activity }\end{array}$ & $\mathrm{pH}<6.5-8.0$ & $\mathrm{pH}<4.6$ & High \\
\hline
\end{tabular}

Notes: ${ }^{a}$ Reference values above which adverse impacts are triggered or amplified. ${ }^{[25,26]}$

${ }^{\mathrm{b}}$ Sodium adsorption ratio, which relates the concentrations of sodium, calcium and magnesium.

'The degradation of organic compounds under aerobic conditions is faster and more complete compared to the anaerobic conditions via, also covering a wider range of compounds.

${ }^{d}$ Excessive retention of water within the plant tissues, which may lead to the lodging of the crops.

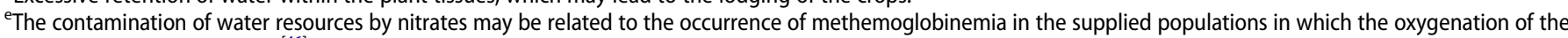
tissues is severely hampered. ${ }^{[46]}$

${ }^{\mathrm{f}}$ The amount of applied nitrogen that triggers negative impacts depends on some factors, including the content of nitrogen in the soil (0.05-2\%), the nutritional requirements of the plant $\left(50-350 \mathrm{~kg} \mathrm{ha}^{-1}\right)$, the application rates and the concentrations of nitrogen in the wastewater. ${ }^{[25]}$

${ }^{9}$ Most of the biological reactions are performed under neutral conditions so that reductions in the $\mathrm{pH}$ directly affect the metabolism of the microorganisms.

of the phytotoxic effects of sulfide on dryland plants, such as sugarcane. Sulfide also exerts toxic effects on the microbial populations acting on the fixation of nutrients and on the conversion of the organic compounds applied to the soil, resulting in increased microbial activity losses.

With respect to the dynamics of organic matter in soil, the controlled input of organic compounds triggers a series of beneficial effects, such as increases in both the moisture content and the CEC, as well as the formation of stable aggregates. ${ }^{[33,36,48]}$ However, the input of excessive levels of organic compounds may lead to the complete depletion of the available oxygen present within both the soil pores and the groundwater, directly reducing the microbial activity, and consequently increasing the soil instability (Table 2). Enhanced microbial activity levels improve the cementation of soil aggregates, as the metabolites excreted by the microorganisms favor the flocculation of the particles. ${ }^{[48]}$ The concentrations of biodegradable organic matter found in the sugarcane vinasse samples analyzed (>14.4 $\mathrm{g} \mathrm{L}^{-1}$, Table 1 ) are much higher than the reference value for safe agricultural reuse $\left(400 \mathrm{mg} \mathrm{L}^{-1}\right.$, Table 2), although the measured levels are at least 1.2- to 1.9-fold lower than those of other conventional feedstocks (Table 1). However, in terms of environmental impact, Mariano et al. ${ }^{[50]}$ observed reductions of up to $90 \%$ in the levels of dissolved oxygen in groundwater $\left(8.3-0.8 \mathrm{mg} \mathrm{L}^{-1}\right)$ after evaluating the role of sugarcane vinasse in the bioremediation of soils contaminated with diesel oil. The authors also reported sharp increases in both the EC $\left(0.30-1.25 \mathrm{dS} \mathrm{m}^{-1}\right)$ and the organic matter level (37.8-1,900 $\mathrm{mg} \mathrm{L}^{-1}$, as COD) in the groundwater. Gunkel et al. ${ }^{[51]}$ also reported an expressive reduction in the dissolved oxygen levels $\left(5.5-2.8 \mathrm{mg} \mathrm{L}^{-1}\right)$ coupled with increasing organic matter concentrations $\left(<2-20.8 \mathrm{mg} \mathrm{L}^{-1}\right.$ and $<15-$ $49.5 \mathrm{mg} \mathrm{L}^{-1}$ for the BOD and COD, respectively) in the water of the Ipojuca River (Pernambuco State, Brazil), which is near an area subjected to long-term sugarcane cultivation. In this case, although the sugarcane vinasse was not directly discharged into the river, as prohibited by the Brazilian legislation, ${ }^{[52]}$ the effluent was carried along with the runoff from the irrigation channels.

Potential negative impacts of fertirrigation with sugarcane vinasse also include soil overfertilization, considering the fate of both nitrogen and phosphorus (Table 2). Excessive levels of nitrogen tend to increase the water content within plant tissues, leading to lodging in grain cultures and losses in the carbohydrate content in sugar-rich feedstocks, such as sugar beet, sugarcane and sweet sorghum. ${ }^{[25,26]}$ Yet considering the fate of nitrogen, the association between high levels of organic nitrogen and biodegradable organic matter stimulates the process of denitrification, which also contributes to the depletion of oxygen. Moreover, under specific conditions of moisture, $\mathrm{pH}$ and availability of both nitrogen and organic matter, the release of intermediate compounds due to denitrification, i.e., nitrogen 
oxides, may be observed, which may increase the emissions of greenhouse gases. ${ }^{[53]}$ Particularly, the emission of nitrous oxide $\left(\mathrm{N}_{2} \mathrm{O}\right)$ is of great concern, as the global warming potential of this gas is over 300 -fold higher than that of carbon dioxide. ${ }^{[54]}$ The leaching of nutrients along with the runoff, similar to organic matter, may also generate important negative effects, considering the eutrophication of fresh water streams (Table 2).

The permanent acidification of both soil and water resources constitutes another potential negative effect resulting from the continuous land disposal of sugarcane vinasse $(\mathrm{pH}<4.3$, Table 1), as detailed in Table 2. The excessive input of acidity into soils stimulates the solubilization of metals, directly affecting the productivity of the crops and reduces the microbial activity. ${ }^{[25]}$ Gunkel et al. ${ }^{[51]}$ also reported a slight water acidification ( $\mathrm{pH}$ decrease from 6.7 to 6.0) when monitoring the quality of the Ipojuca River under the influence of sugarcane vinasse; more evident effects should be expected in groundwater and lentic systems, such as lakes, due to the low-to-null flow velocity.

\section{Toxic metals in sugarcane vinasse}

A lack of studies addressing the occurrence and fate of toxic metals in areas subjected to the land disposal of vinasse is commonly observed, as the literature tends to classify this residual stream as poor wastewater in terms of these metals. ${ }^{[18]}$ However, a few specific studies have revealed high levels of toxic metals in sugarcane vinasse samples, with an emphasis on the presence of phytotoxic elements, such as $\mathrm{Al}, \mathrm{Cl}$ and $\mathrm{Fe}$, and priority pollutants, including $\mathrm{Cd}, \mathrm{Cr}, \mathrm{Cu}, \mathrm{Pb}, \mathrm{Ni}$ and $\mathrm{Zn}$. Nandan et al. ${ }^{[55]}$ reported $\mathrm{Pb}, \mathrm{Cu}$ and Zn levels as high as $8.8,15.7$ and $11.8 \mathrm{mg} \mathrm{L}^{-1}$, respectively, in vinasse samples from sugarcane molasses. Chandra et al. ${ }^{[56]}$ indicated concentrations of 2.28, 4.45, 1.24, 4.63 and $0.95 \mathrm{mg} \mathrm{L}^{-1}$ for $\mathrm{Cd}, \mathrm{Pb}, \mathrm{Ni}, \mathrm{Zn}$ and $\mathrm{Cu}$, respectively, whereas $\mathrm{Cu}, \mathrm{Cd}, \mathrm{Cr}, \mathrm{Zn}, \mathrm{Ni}$ and $\mathrm{Pb}$ levels reached 3.12, 2.37, 3.03, 14.11, 2.24 and $1.46 \mathrm{mg}$ $\mathrm{L}^{-1}$, respectively, as stated by Chandra et al., ${ }^{[57]}$ who also considered vinasse samples from sugarcane molasses' processing. Table 3 compiles the concentrations of some toxic metals identified in the samples of sugarcane vinasse analyzed in this study and compares these levels with reference values reported in normative instructions dealing with water discharge and the agricultural reuse of wastewaters. Differences in the reference values for metal concentrations in the normative instructions result primarily from their scope, as well as specific restrictions in the environmental legislations. Overall, water discharge-based reference values (Tchobanoglous et al. ${ }^{[58]}$ ) are lower compared to cases dealing with the land application of wastewaters through fertirrigation $\left(\mathrm{WHO}^{[25]}\right)$, as in the last case, several mechanisms (e.g., soil adsorption, uptake by plants and dilution by rain) will naturally reduce metal concentrations in the wastewater before the runoff reaches water bodies. Nevertheless, the use of diversified reference values to assess the polluting potential of sugarcane vinasse in terms of toxic metals is required to foresee the fate of these constituents in fertirrigated areas, given the reduced availability of reference studies dealing with this particular compositional aspect.

Priority pollutants were identified in the samples monitored herein, although the values obtained are much less than those previously reported by Nandan et al. ${ }^{[55]}$ and Chandra et al. ${ }^{[56,57]}$. An overall analysis indicates that $\mathrm{Cu}, \mathrm{Cr}, \mathrm{Ni}$ and $\mathrm{Zn}$ concentrations reached levels above the water discharge limits as indicated by Tchobanoglous et al. ${ }^{[58]}$ in all the vinasse samples, with measured values ranging from 134.0 to $668.0,26.0$ to $56.0,31.0$ to 147.0 and 251.0 to $431.0 \mu \mathrm{g} \mathrm{L}^{-1}$, respectively (Table 3). The concentration of $\mathrm{Pb}$ was below the reference value for water discharge in only one of the samples $(4.0 \mu \mathrm{g}$ $\mathrm{L}^{-1}$, DsSL - Table 3 ). However, priority pollutants' concentrations were usually much lower than the limits established for the agricultural reuse of wastewaters reported by $\mathrm{WHO},{ }^{[25]}$ indicating that contamination events by toxic metals in areas subjected to the application of sugarcane vinasse should not be observed. Nevertheless, the determination of toxic metals in vinasse may still be characterized as a relevant aspect, considering the harmful effects to human populations eventually supplied with contaminated water resources. $\mathrm{Cd}, \mathrm{Cr}$ and $\mathrm{Ni}$ are carcinogenic elements and they affect the renal and gastrointestinal systems after long-term exposure. ${ }^{[59]} \mathrm{Pb}, \mathrm{Cu}$ and $\mathrm{Zn}$ are also harmful to the gastrointestinal system, whereas continuous exposure to high $\mathrm{Pb}$ levels affects the central nervous system and severely inhibits basic cell functions. ${ }^{[59]}$

With respect to the toxicity to plants, specifically using the limits established for the agricultural reuse of wastewaters reported by $\mathrm{WHO},{ }^{[25]}$ the high levels of $\mathrm{Al}\left(>5,000.0 \mu \mathrm{g} \mathrm{L}^{-1}\right.$,

Table 3. Concentrations of metals $\left(\mu \mathrm{g} \mathrm{L}^{-1}\right)$ determined in the vinasse samples and reference values for the water discharge and agricultural reuse of wastewaters.

\begin{tabular}{|c|c|c|c|c|c|c|c|}
\hline Metal & \multicolumn{3}{|c|}{ Normative instruction/environmental legislation ${ }^{\mathrm{a}}$} & \multicolumn{4}{|c|}{ Sugarcane vinasse samples } \\
\hline $\mathrm{Pb}$ & 5.6 & $5,000.0$ & 500.0 & 40.0 & 4.0 & 16.0 & 410.0 \\
\hline $\mathrm{Cu}$ & 4.9 & 200.0 & $1,000.0$ & 668.0 & 263.0 & 134.0 & 268.0 \\
\hline $\mathrm{Cr}$ & 11.0 & 100.0 & 100.0 & 56.0 & 26.0 & 26.0 & 42.0 \\
\hline Mo & nd & 10.0 & nd & 8.0 & 5.0 & 11.0 & $2,000.0$ \\
\hline $\mathrm{Ni}$ & 7.1 & 200.0 & $2,000.0$ & 54.0 & 31.0 & 36.0 & 147.0 \\
\hline $\mathrm{Zn}$ & 58.0 & $2,000.0$ & $5,000.0$ & 431.0 & 288.0 & 251.0 & 382.0 \\
\hline
\end{tabular}

Notes: ${ }^{a}$ Values in $\mu \mathrm{g} \mathrm{L}^{-1}$.

${ }^{\mathrm{b}}$ Typical discharge limits for metals in secondary effluents, according to US normative instructions.

'Threshold levels of trace elements for crop irrigation.

${ }^{d}$ Reference limits for the discharge of effluents into water bodies (maximum permissible values); values in bold characterize concentrations above at least one of the recommended limits in the normative instructions; $n d=$ reference values not established. 
as observed in three of the four samples analyzed - Table 3) may severely reduce the uptake of nutrients by plants due to structural modifications in the root zone, whereas Fe enhances the loss of essential nutrients, such as phosphorus and molybdenum, by forming chemical complexes that are not absorbed by plants. ${ }^{[25,26]}$ Considering the higher solubility of metals under acidic conditions, ${ }^{[25]}$ the low $\mathrm{pH}$ of vinasse tends to amplify these adverse impacts because the mobility of the metals in the soil is increased. ${ }^{[60]}$ The release of organic acids via the anaerobic degradation of the organic matter is also intimately associated with this process because the active sites of the minerals are saturated with metabolites instead of the metallic species. Therefore, phytotoxic effects may be more relevant than contamination by priority pollutants in fertirrigated areas.

The occurrence of metals in vinasse is most likely associated with the corrosion of metallic structures due to the aggressive process conditions employed in the ethanol production chain, primarily the addition of acid in specific steps and the high temperatures employed. ${ }^{[3,56]}$ Although corrosion-resistant alloys are utilized in the construction of fermenters, distillation columns and pipelines, the leaching of metals may occur, primarily when using low-quality materials and/or old machinery, which should explain the presence of some metals, such as $\mathrm{Cd}$, $\mathrm{Pb}$ and $\mathrm{Zn}$, in vinasse. Additional sources of metallic species in vinasse include both the use of chemicals within the production chain and the absorption of metals present in the soil by plants. Particularly, the last process may explain the high concentrations of $\mathrm{Al}$ and $\mathrm{Fe}$ in vinasses from feedstocks cultivated under tropical conditions, such as sugarcane, based on the influence of weathering on Al- and Fe-rich minerals, i.e., kaolinite, gibbsite and hematite. ${ }^{[61]}$

\section{Outlook: Perspectives for the management of sugarcane vinasse}

The compositional data presented and discussed in this study clearly indicate that the land disposal of sugarcane vinasse may trigger a large variety of negative effects on the environment, particularly on the soil. However, note that the magnitude of these impacts depends directly on the climatic conditions and the type of soil. Specific aspects, such as the mineral composition and the natural organic matter content of the soil, affect the interactions between the applied inorganic and organic compounds and the components of the terrain, favoring the leaching or retention of salts and organic matter. The compositional variability of the vinasse throughout the harvesting period should also be considered, regarding the influence of the levels of biodegradable organic matter and salts. Higher sugar production rates increase the volumes of molasses directed toward the production of ethanol (Fig. 1), providing a more recalcitrant characteristic to the organic matter found in vinasse. Moreover, higher salt levels should also be observed to amplify specific impacts, such as soil salinization. ${ }^{[3,8]}$ In contrast, the direct application of sugarcane juice to fermenters (autonomous ethanol plants) provides more diluted streams in terms of salts, although higher levels of biodegradable organic matter, i.e., BOD, are observed. Nevertheless, despite this variability, high organic matter $\left(\mathrm{COD}>15 \mathrm{~g} \mathrm{~L}^{-1}\right)$ and salt concentrations (e.g., sulfate $>600 \mathrm{mg} \mathrm{L}^{-1}$ and potassium $>1,200 \mathrm{mg} \mathrm{L}^{-1}$ ) will inevitably be found in sugarcane vinasse, using compositional characteristics from residual streams in autonomous plants as a reference. ${ }^{[62]}$ Therefore, the major environmental impacts described herein may be potentially triggered in all fertirrigated areas, irrespective of the origin of the vinasse.

The aforementioned characteristics highlight the need for long-term studies, i.e., over one or two decades, to better identify and quantify the environmental impacts associated with the reuse of sugarcane vinasse via fertirrigation. Simultaneously, the definition of treatment layouts to reduce the polluting load of vinasse is required in an effort to combine the environmental adequacy of the reuse process with the recovery of bioresources, as proposed by the concept of biorefinery. ${ }^{[13]}$ Anaerobic digestion has been shown to be the most suitable approach for reducing the organic matter content of vinasse, as well as for enabling the recovery of bioenergy through biogas production. ${ }^{[8,63]}$ However, additional treatment steps are still required to remove the residual levels of both organic matter and salts. Although the literature reports the application of advanced electrochemical and oxidative treatment processes, such as electrocoagulation and the Fenton process, ${ }^{[64,65]}$ the application of conventional physical-chemical processes, such as coagulation-flocculation and/or adsorption, ${ }^{[17,66,67]}$ may be the key to providing the most cost-effective results. However, in contrast to anaerobic digestion, a considerable amount of research is still required to define the most suitable post-treatment methods for the treatment of sugarcane vinasse.

One last remark should be considered in terms of the calculation of the rates for the application of vinasse to soils. Focusing on the Brazilian case, the contents of potassium in both the vinasse and the soil are the sole parameters considered for this calculation, specifically for the São Paulo State (Eq. (2) $)^{[23]}$; the dosages of other compounds, such as nitrogen, sulfates and organic matter, are not properly controlled. The criteria for the land disposal of sugarcane vinasse should be defined from a more holistic perspective, considering at least the content of organic nitrogen and biodegradable organic matter, which may trigger the most significant negative effects in association with the high salt concentrations, as discussed in detail in this study. For these purposes, a database including a complete characterization of sugarcane vinasse streams should be constructed to associate compositional variations with specific periods of the season and the type of agricultural soils so that the combination of this information may lead to a more complete and flexible methodology for the calculation of the application rate

$$
\mathrm{APR}_{\mathrm{SV}}=\frac{\left(0.05 \cdot \mathrm{CEC}-[\mathrm{K}]_{\text {soil }}\right) \cdot 3,744+185}{[\mathrm{~K}]_{\text {vinasse }}}
$$

In Eq. (2), the terms $\mathrm{APR}_{\mathrm{SV}}, \mathrm{CEC},[\mathrm{K}]_{\text {soil }}$ and $[\mathrm{K}]_{\text {vinasse }}$ are the application rate of sugarcane vinasse $\left(\mathrm{m}^{3} \mathrm{ha}^{-1}\right)$, the CEC of the soil ( $\mathrm{cmolc} \mathrm{dm}^{-3}$ ), the concentration of potassium in the soil at a depth of up to $0.8 \mathrm{~m}\left(\mathrm{cmolc} \mathrm{dm}^{-3}\right)$ and the concentration of potassium in sugarcane vinasse $\left(\mathrm{kg} \mathrm{K}_{2} \mathrm{O} \mathrm{m}{ }^{-3}\right)$, respectively. The value 3,744 represents the factor for converting 
potassium concentrations from cmolc $\mathrm{dm}^{-3}$ to $\mathrm{kg}$ per a volume of $8,000 \mathrm{~m}^{3}(1 \mathrm{ha} \times 0.8 \mathrm{~m})$. The value 185 represents the mass of $\mathrm{K}_{2} \mathrm{O}$ extracted by the crop by hectare during the season.

\section{Conclusion}

The compositional data used in this study enabled characterizing a series of negative impacts potentially triggered by the application of raw sugarcane vinasse into soils. The primary environmental impacts from the continuous land disposal of vinasse are soil salinization and organic overloading, considering the high inputs of salts and biodegradable organic matter into the systems. Regarding metal toxicity, phytotoxic effects should be more relevant than contamination by priority pollutants in fertirrigated areas, considering the high concentrations of specific elements, namely $\mathrm{Al}$ and $\mathrm{Fe}$. An overall analysis indicated that specific measures must be considered to achieve a more reasonable reuse of sugarcane vinasse. These measures include the application of treatment processes to attain both environmental adequacy and resource recovery, a proper characterization of the vinasse streams to construct a complete database correlating compositional variations with specificities of the cultivation area and the season, and the definition of more adequate methodologies to calculate the application rates.

\section{Funding}

The authors are grateful to the São Paulo Research Foundation (Fapesp) (Grant numbers 2009/15984-0, 2010/04101-8 and 2014/04636-0) and to the National Council for Scientific and Technological Development (CNPq) (Grant number 470010/2013-4) for financially supporting the development of this study.

\section{References}

[1] Báez-Vásquez, M.A.; Demain, A.L. Ethanol, biomass, and Clostridia. In Bioenergy; Wall, J.D.; Harwood, C.S.; Demain, A., Eds.; ASM Press: Washington, DC, 2008; 49-54.

[2] Cavalett, O.; Junqueira, T.L.; Dias, M.O.S.; Jesus, C.D.F.; Mantelatto, P.E.; Cunha, M.P.; Franco, H.J.C.; Cardoso, T.F.; Maciel Filho, R.; Rossell, C.E.V.; Bonomi, A. Environmental and economic assessment of sugarcane first generation biorefineries in Brazil. Clean Technol. Environ. 2012, 14(3), 399-410.

[3] Fuess, L.T.; Garcia, M.L. Implications of stillage land disposal: a critical review on the impacts of fertigation. J. Environ. Manage. 2014, $145,210-229$.

[4] CONAB. Acompanhamento da Safra Brasileira: Cana-de-açúcar, Quarto Levantamento, Abril/2015 [Monitoring of the Brazilian Crop: Sugarcane, Fourth Survey, April/2015]; CONAB: Brasília, Brazil, 2015; $1-29$.

[5] EIA. Monthly Energy Review, June 2016; DOE/EIA-0035(2016/06); U.S. Energy Information Administration: Washington, DC, 2016; 1224. https://www.eia.gov/totalenergy/data/monthly/pdf/mer.pdf. Accessed 26 June 2016

[6] BNDES; CGEE. Bioetanol de Cana-de-açúcar: Energia Para o Desenvolvimento Sustentável [Bioethanol from Sugarcane: Energy for Sustainable Development], 1st ed.; BNDES: Rio de Janeiro, Brazil, 2008, 316.

[7] Dias, M.O.S.; Junqueira, T.L.; Cavalett, O.; Pavanello, L.G.; Cunha, M.P.; Jesus, C.D.F.; Maciel Filho, R.; Bonomi, A. Biorefineries for the production of first and second generation ethanol and electricity from sugarcane. Appl. Energy 2013, 109, 72-78.
[8] Fuess, L.T.; Garcia, M.L. Bioenergy from stillage anaerobic digestion to enhance the energy balance ratio of ethanol production. J. Environ. Manage. 2015, 162, 102-114.

[9] Goldemberg, J.; Coelho, S.T.; Guardabassi, P. The sustainability of ethanol production from sugarcane. Energy Policy 2008, 36(6), 2086-2097.

[10] España-Gamboa, E.; Mijangos-Cortes, J.; Barahona-Perez, L.; Dominguez-Maldonado, J.; Hernández-Zarate, G.; Alzate-Gaviria, L. Vinasses: characterization and treatments. Waste Manage. Res. 2011 29(12), 1235-1250.

[11] Christofoletti, C.A.; Escher, J.P.; Correia, J.E.; Marinho, J.F.; Fontanetti, C.S. Sugarcane vinasse: environmental implications of its use. Waste Manage. 2013, 33(12), 2752-2761.

[12] Akram, M.; Tan, C.K.; Garwood, R.; Thai, S.M. Vinasse - A potential biofuel - Cofiring with coal in a fluidised bed combustor. Fuel 2015, $158,1006-1015$

[13] Moraes, B.S.; Zaiat, M.; Bonomi, A. Anaerobic digestion of vinasse from sugarcane ethanol production in Brazil: challenges and perspectives. Renew. Sustain. Energy Rev. 2015, 44, 888-903.

[14] Brito, F.L.; Rolim, M.M.; Pedrosa, E.M.R. Efeito da aplicação de vinhaça nas características de solos da zona da mata de Pernambuco [Effect of vinasse application in chemical characteristics of soils from forest zone of Pernambuco]. Agrária 2009, 4(4), 456-462.

[15] Uyeda, C.A.; Miranda, J.H.; Duarte, S.N.; Medeiros, P.R.F.; Dias, C.T S. Influence of vinasse application in hydraulic conductivity of three soils. Eng. Agríc. 2013, 33(4), 689-698.

[16] Zolin, C.A.; Paulino, J.; Bertonha, A.; Freitas, P.S.L.; Folegatti, M.V. Estudo exploratório do uso da vinhaça ao longo do tempo. I. Características do solo [Exploratory study of the stillage use along the time. I. Characteristics of the soil]. Rev. Bras. Eng. Agríc. Ambient. 2011, 15(1), 22-28.

[17] Guerreiro, L.F.; Rodrigues, C.S.D.; Duda, R.M.; Oliveira, R.A.; Boaventura, R.A.R.; Madeira, L.M. Treatment of sugarcane vinasse by combination of coagulation/flocculation and Fenton's oxidation. J. Environ. Manage. 2016, 181, 237-248.

[18] Moran-Salazar, R.G.; Sanchez-Lizarraga, A.L.; Rodriguez-Campos, J.; Davila-Vazquez, G.; Marino-Marmolejo, E.N.; Dendooven, L.; Contreras-Ramos, S.M. Utilization of vinasses as soil amendment: consequences and perspectives. Springerplus 2016, 5(1):1007.

[19] APHA; AWWA; WEF. Standard Methods for the Examination of Water and Wastewater, 22nd ed.; APHA: Washington, DC, 2012, 1496.

[20] EPA. Determination of Total Kjeldahl Nitrogen by Semi-automated Colorimetry, Revision 2.0; Method 351.2; U.S. Environmental Protection Agency: Cincinnati, OH, 1993.

[21] EPA. Microwave Assisted Acid Digestion of Aqueous Samples and Extracts, Revision 1, Method 3015A; U.S. Environmental Protection Agency: Cincinnati, OH, 2007.

[22] EPA. Determination of Metals and Trace Elements in Water and Wastes by Inductively Coupled Plasma-Atomic Emission Spectrometry, Revision 4.4, Method 200.7; U.S. Environmental Protection Agency: Cincinnati, OH, 1994.

[23] CETESB. Vinhaça - Critérios e Procedimentos Para Aplicação no Solo Agrícola. [Stillage - Criteria and Procedures for Agricultural Soil Application], Norma P4.231, 3rd ed.; CETESB: São Paulo, 2015.

[24] Brasil. Resolução Conama n. 430, de 13 de maio de 2011. Dispõe Sobre as Condições e Padrões de Lançamento de Efluentes, Complementa e Altera a Resolução n, 357, de 17 de Março de 2005, do Conama. Conama: Brasília, 2011.

[25] WHO. Guidelines for the Safe Use of Wastewater, Excreta and Greywater; Volume II: Wastewater Use in Agriculture. Geneva, Switzerland: WHO, 2006, 196.

[26] EPA. 2012 Guidelines for Water Reuse; EPA/600/R-12/618; U.S. Environmental Protection Agency: Cincinnati, OH, 2012.

[27] Arienzo, M.; Christen, E.W.; Quayle, W.; Kumar, A. A review of the fate of potassium in the soil-plant system after land application of wastewaters. J. Hazard. Mater. 2009, 164(2-3), 415-422.

[28] Rolim, M.M.; Lyra, M.R.C.C.; Duarte, A.S.; Medeiros, P.R.F.; França e Silva, E.F.; Pedrosa, E.M.R. Influência de Uma Lagoa de Distribuição de Vinhaça na Qualidade da Água Freática [Influence of a 
Vinasse-distributing Lake on Water Quality of the Groundwater]. Rev. Ambient. Água. 2013, 8(1), 155-171.

[29] CGEE. Bioetanol Combustível: Uma Oportunidade Para o Brasil [Fuel Bioethanol: An Opportunity for Brazil], CGEE: Brasília, Brazil, 2009, 536.

[30] Silva, G.A. Avaliação das Tecnologias de Disposição de Vinhaça de Cana-de-açúcar Quanto ao Aspecto de Desenvolvimento Ambiental e Econômico [Evaluation of Technologies FOR THE Disposal of Sugarcane Vinasse in Terms of Environmental and Economic Development] (Doctoral thesis). São Carlos, SP, Brazil: University of São Paulo, 2012.

[31] Pathak, H.; Joshi, H.C.; Chaudhary, A.; Chaudhary, R.; Kalra, N.; Dwiwedi, M.K. Soil amendment with distillery effluent for wheat and rice cultivation. Water Air Soil Pollut. 1999, 133(1), 133-140.

[32] Banu, J.R.; Kaliappan, S.; Rajkumar, M.; Beck, D. Treatment of spent wash in anaerobic mesophilic suspended growth reactor (AMSGR). J. Environ. Biol. 2006, 27(1), 111-117.

[33] Hati, K.; Biswas, A.; Bandyopadhyay, K.; Misra, A. Soil properties and crop yields on a vertisol in India with application of distillery effluent. Soil Till. Res. 2007, 92(1-2), 60-68.

[34] Kumar, S.G.; Gupta, S.K.; Singh, G. Biodegradation of distillery spent wash in anaerobic hybrid reactor. Water Res. 2007, 41(4), 721-730.

[35] Acharya, B.K.; Mohana, S.; Madamwar, D. Anaerobic treatment of distillery spent wash - A study on upflow anaerobic fixed film bioreactor. Bioresour. Technol. 2008, 99(11), 4621-4626.

[36] Biswas, A.K.; Mohanty, M.; Hati, K.M.; Misra, A.K. Distillery effluents effect on soil organic carbon and aggregate stability of a Vertisol in India. Soil Till. Res. 2009, 104(2), 241-246.

[37] Alkan-Ozkaynak, A.; Karthikeyan, K.G. Anaerobic digestion of thin stillage for energy recovery and water reuse in corn-ethanol plants. Bioresour. Technol. 2011, 102(21), 9891-9896.

[38] Nasr, N.; Elbeshbishy, E.; Hafez, H.; Nakhla, G.; El Naggar, M.H. Biohydrogen production from thin stillage using conventional and acclimatized anaerobic digester sludge. Int. J. Hydrogen Energy 2011, 36 (20), 12761-12769.

[39] Andalib, M.; Hafez, H.; Elbeshbishy, E.; Nakhla, G.; Zhu, J. Treatment of thin stillage in a high-rate anaerobic fluidized bed bioreactor (AFBR). Bioresour. Technol. 2012, 121, 411-418.

[40] Wilkinson, A.; Kennedy, K.J. Anaerobic digestion of corn ethanol thin stillage in batch and by high-rate down-flow fixed film reactors. Water Sci. Technol. 2012, 66(9), 1834-1841.

[41] Vlissidis, A.; Zouboulis, A.I. Thermophilic anaerobic digestion of alcohol distillery wastewaters. Bioresour. Technol. 1993, 43(2), 131140.

[42] Jiménez, A.M.; Borja, R.; Martín, A. Aerobic-anaerobic biodegradation of beet molasses alcoholic fermentation wastewater. Process Biochem. 2003, 38(9), 1275-1284.

[43] Lutosławski, K.; Ryznar-Luty, A.; Cibis, E.; Krzywonos, M.; Miśkiewicz, T. Biodegradation of beet molasses vinasse by a mixed culture of micro organisms: effect of aeration conditions and $\mathrm{pH}$ control. J. Environ. Sci. (China) 2011, 23(11), 1823-1830.

[44] Auerswald, K.; Kainz, M.; Angermüller, S.; Steindl, H. Influence of exchangeable potassium on soil erodibility. Soil Use Manage. 1996, 12(3), 117-121.

[45] Tsiropoulos, I.; Faaij, A.P.C.; Lundquist, L.; Schenker, U.; Briois, J.F.; Patel, M.K. Life cycle impact assessment of bio-based plastics from sugarcane ethanol. J. Clean. Prod. 2015, 90, 114-127.

[46] Batalha, B.H.L.; Parlatore, A.C. Controle da Qualidade de Água Para Consumo Humano: Bases Conceituais e Operacionais [Quality Control of Water for Human Consumption: Conceptual and Operational Bases], CETESB: São Paulo, Brazil, 1993, 198.

[47] Tejada, M.; Gonzalez, J.L. Effects of two beet vinasse forms on soil physical properties and soil loss. Catena 2006, 68(1), 41-50.

[48] Tejada, M.; Moreno, J.L.; Hernandez, M.T.; Garcia, C. Application of two beet vinasse forms in soil restoration: effects on soil properties in an arid environment in southern Spain. Agric. Ecosyst. Environ. 2007, 119(3-4), 289-298.
[49] Lamers, L.P.M.; Govers, L.L.; Janssen, I.C.J.M.; Geurts, J.J.M.; Van der Welle, M.E.W.; Van Katwijk, M.M.; Van der Heide, T.; Roelofs, J. G.M.; Smolders, A.J.P. Sulfide as a soil phytotoxin - A review. Front. Plant Sci. 2013, 4, 268.

[50] Mariano, A.P.; Crivelaro, S.H.R.; Angelis, D.F.; Bonotto, D.M. The use of vinasse as an amendment to ex-situ bioremediation of soil and groundwater contaminated with diesel oil. Braz. Arch. Biol. Technol. 2009, 52(4), 1043-1055.

[51] Gunkel, G.; Kosmol, J.; Sobral, M.; Rohn, H.; Montenegro, S., Aureliano, J. Sugar cane industry as a source of water pollution - Case study on the situation in Ipojuca river, Pernambuco, Brazil. Water Air Soil Pollut. 2007, 180(1-4), 261-269.

[52] Brasil. Portaria: GM MINTER n. 323, de 29 de novembro de 1978, MINTER: Brasília, 1978

[53] Carmo, J.B.; Filoso, S.; Zotelli, L.C.; Sousa Neto, E.R.; Pitombo, L.M.; Duarte-Neto, P.J.; Vargas, V.P.; Andrade, C.A.; Gava, G.J.C.; Rossetto, R.; Cantarella, H.; Neto, A.E.; Martinelli, L.A. Infield greenhouse gas emissions from sugarcane soils in Brazil: Effects from synthetic and organic fertilizer application and crop trash accumulation. GCB Bioenergy 2013, 5(3), 267-280.

[54] Oliveira, B.G.; Carvalho, J.L.N.; Cerri, C.E.P.; Cerri, C.C.; Feigl, B.J. Soil greenhouse gas fluxes from vinasse application in Brazilian sugarcane areas. Geoderma 2013, 200-201, 77-84.

[55] Nandan, R.; Tondwalkar, V.; Ray, P.K. Biomethanation of spent wash: Heavy metal inhibition of methanogenesis in synthetic medium. J. Ferment. Bioeng. 1990, 69(5), 276-282.

[56] Chandra, R.; Yadav, S.; Bharagava, R.N.; Murthy, R.C. Bacterial pretreatment enhances removal of heavy metals during treatment of post-methanated distillery effluent by Typha angustata L. J. Environ. Manage. 2008, 88(4), 1016-1024.

[57] Chandra, R.; Bharagava, R.N.; Yadav, S.; Mohan, D. Accumulation and distribution of toxic metals in wheat (Triticum aestivum L.) and Indian mustard (Brassica campestris L.) irrigated with distillery and tannery effluents. J. Hazard. Mater. 2009, 162(2-3), 1514-1521.

[58] Tchobanoglous, G.; Burton, F.L.; Stensel, H.D.; Metcalf \& Eddy. Wastewater Engineering: Treatment and Reuse, 4th ed.; McGraw-Hill Inc.: New York, 2003, 1819.

[59] Fu, F.; Wang, Q. Removal of heavy metal ions from wastewaters: a review. J. Environ. Manage. 2011, 92(3), 407-418.

[60] Souza, T.; Hencklein, F.A.; Angelis, D.F.; Fontanetti, C.S. Clastogenicity of landfarming soil treated with sugar cane vinasse. Environ. Monit. Assess. 2013, 185(2), 1627-1636.

[61] Costa, A.C.S.; Almeida, V.C.; Lenzi, E.; Nozaki, J. Determinação de Cobre, Alumínio e Ferro em Solos Derivados do Basalto Através de Extrações Seqüenciais [Determination of copper, aluminum, and iron in basaltic soils by sequential extractions]. Quím. Nova 2002, 25 (4), 548-552.

[62] Costa, F.J.C.B.; Rocha, B.B.M.; Viana, C.E.; Toledo, A.C. Utilization of vinasse effluents from an anaerobic reactor. Water Sci. Technol. 1986, 18(12), 135-141.

[63] Moraes, B.S.; Junqueira, T.L.; Pavanello, L.G.; Cavalett, O.; Mantelatto, P.E.; Bonomi, A.; Zaiat, M. Anaerobic digestion of vinasse from sugarcane biorefineries in Brazil from energy, environmental, and economic perspectives: Profit or expense? Appl. Energy 2014, 113, 825-835.

[64] Yavuz, Y. EC and EF processes for the treatment of alcohol distillery wastewater. Sep. Purif. Technol. 2007, 53(1), 135-140.

[65] Zayas, T.; Rómero, V.; Salgado, L.; Meraz, M.; Morales, U. Applicability of coagulation/flocculation and electrochemical processes to the purification of biologically treated vinasse effluent. Sep. Purif. Technol. 2007, 57(2), 270-276.

[66] Rodrigues, I.J.; Fuess, L.T.; Biondo, L.; Santesso, C.A.; Garcia, M.L. Coagulation-flocculation of anaerobically treated sugarcane stillage. Desalin. Water Treat. 2014, 52(22-24), 4111-4121.

[67] Seixas, F.L.; Gimenes, M.L.; Fernandes-Machado, N.R.C. Tratamento da Vinhaça por Adsorção em Carvão de Bagaço de Cana-de-açúcar [Treatment of Vinasse by Adsorption on Carbon from Sugar cane Bagasse]. Quím. Nova 2016, 39(2), 172-179. 